\title{
CONFUCIUS AND CONFUCIANISM
}

BY H. G. CREEL

$\mathrm{T}$ HE most famous exponent of Sinism was K'ung Fu Tse, or, as his name is latinized, Confucius (551-479 B.C.). ${ }^{183}$ The son of an obscure military officer in the state of Lu, he was orphaned early. The Analects tell us that he had no teacher, but studied the ancient books and traditions for himself. This seems probable. He worked his way up in the government of Lu until he became one of the chief ministers of the state. As a protest against the improper actions of ihe Marquis who employed him he resigned, as the code of his class required, at the height of his career. He went thereafter from one state to another seeking employment, but was unable to find a permanent post. Later, he settled down with a circle of disciples about him to teach and to write. He edited the Shu King and the Shi King, but his original compositions include only the Ch'un Ch'iut and, probably, one of the appendices to the $Y i K i n g$.

Confucius has been greatly misunderstood and greatly misinterpreted to the West. Beyond doubt this is due to the fact that the teaching which bears his name formed the strongest bulwark against the entrance of Christianity into the country. In requital, such scholars as Wieger have, perhaps not deliberately, but thoroughly, misrepresented him.

In the Occident he is believed, at least popularly, to have originated Sinism. This has already been shown to be untrue. On the basis of the Analects (our most reliable source of information

183 Wieger, Histoire acs Croyances, p. 123.

184 This book is a brief, laconic, and unembellished record of events. Several commentaries have been written on it, and numerous commentaries have been written on these commentaries. The book is supposed to have accorded praise or blame to the persons mentioned, by means of extremely delicate niceties of phrasing. It was probably written with this intent. See Legge's preface to the book in the Chinese Classics. 
concerning the Sage) it may be seen that he was conspicuously unoriginal as compared with his famous contemporary, Lao Tse, and as compared with the outstanding Chinese thinkers of the centuries which followed him. His teachings are almost entirely a setting forth and elaboration of the philosophy stated in the Shu and the Shi; many of his statements in the Analects are taken verbatim from these sources. Confucius did not pretend to be original.

On the other hand, he has been represented as having been, personally, almost entirely negative, an inhuman, formal, stiff. timid prig. Nothing could be farther from the truth. The Confucius who is revealed by an unprejudiced reading of the Analects is modest, kindly, earnest, sincere, above all "human." It is, in my. opinion, his greatness of character, not exceeded by any figure in world-history, rather than his intellect, which makes him significant for the history of Chinese thought. Confucius lived in a time when all of the old standards were being thrown over, due to the breakdown of the Chow dynasty. The system of thought which we have been sketching had been in existence long before his time, and had been expounded by many men before him. But Confucius, by the force of his personal greatness, was able to catch the imagination of men, and eventually, through his disciples, to reinstate the old philosophy, to some extent, for another two thousand five hundred years.

Part of the injustice done to Confucius derives from the error of considering him the originator of Sinism. To be sure, he insists on formalism, but in this he only attempts to better the ordering of human affairs in the way which had been prescribed from antiquity. In so far as he allows his personal preferences to intrude, he figures as a rationalizer and humanizer of the old formulas.

The Master said, "The linen cap is that which is prescribed by the rules of ceremony, but now a silk one is worn. It is economical, and I follow the common practice.

The rules of ceremony prescribe the bowing below the hall, but now the practice is to bow only after ascending it. That is arrogant. I continue to bow below the hall, though I oppose the common practice." 185

In the ceremonies of mourning, it is better that there should be deep sorrow than a minute attention to observances. ${ }^{186}$ The Master said, " 'It is $l i,{ }^{, 187}$ they say 'It is $l i$,' they say.

185. Analects, 9,3.

186 Ibid., $3,4,3$.

187 I. e., "It is according to the rules of propriety." 
Are gems and silk all that is meant by $l i$ ? 'It is music,'188 they say. 'It is music,' they say. Are bells and drums all that is meant by music?" 189

The Master said, "High station filled without indulgent generosity; ceremonies performed without reverence; mourning conducted without sorrow;--wherewith should I contemplate such ways ?190

The Master said, "Though a man have abilities as admirable as those of the Duke of Chow, yet if he be proud and niggardly, those other things are not really worth being looked at. ${ }^{191}$

Confucius' way of following the tao, which was the way prescribed in the $S h u$ and the $S h i$, was to study carefully the methods of the successful emperors and dyrasties of the past, and then to apply them.

The Master said, "Follow the seasons of Hsia.

"Ride in the state carriage of Yin.

"Wear the ceremonial cap of Chow.

"Let the music be the Shao (the music of Shun) with its pantomimes." 192

The Master said, "Without knowing the ordinances of Heaven, it is impossible to be a superior man.

"Without knowing li (the rules of propriety), it is impossible for the character to be established."193

Confucius puts great emphasis, therefore, on learning and study. ${ }^{194}$ He does not, however, allow himself to become entangled in the philosopher's error of mistaking words for things, ${ }^{195}$ nor does he, in setting up the past as criterion, leave no room for growth. ${ }^{196}$

The picture of Confucius the man can be painted most accurately by a few quotations from the Analects. A disciple said of him:

There were four things from which the Master was entirely free. He had no foregone conclusions, no arbitrary predeterminations, no obstinacy, no egoism. ${ }^{197}$

He himself said:

To conceal resentment against a person, and appear friend188 Chinese music of this period had deep moral and ceremonial significance. 189 Ibid., 17.11 .

190 Ibid., 3,26 .

191 Ibid., 6,11.

192 Ibid., 15,10

193 Ibid., 20,3.

194 Ibid., 2,$16 ; 8,12 ; 11,24$.

195 Ibid., 15,40.

196 Ibid., 3.14; Cf. also Li Ki (in C.C.), p. 390.

197 An. 9,4. 
1y with him :-Tso Ch"ît-ming was ashamed of such conduct. I also am ashamed of it. ${ }^{198}$

The Master angled, but he did not use a net. He shot, but not at birds perching. ${ }^{199}$

The Naster said, "In letters, I am perhaps equal to other men, but the character of the superior man, in carrying out in his conduct what he professes, is what I have not yet attained to. ${ }^{200}$

The Master said, "A youth is to be regarded with respect. How do we know that his future will not be equal to our present ?'201

When any of his [Confucius'] friends died, if he had no relations who could be depended upon for the necessary offices, he would say, "I will bury him." 202

Actual incidents related of the Sage show him as unusually kindly and considerate. ${ }^{202 a}$ It nutst be remembered, also, that the things which are said of him are not of the sort of myth with which the disciples of every great man seek to glorify him. Legends about Confucius abound, but we are not dealing here with those. Most of the material in the Analects rings true. If the reader doubt, let him take two or three hours to read through the book himself.

There is little of the dilettante or the pedant about Confucius. He is tremendously in earnest.

Though a man may be able to recite the three hundred odes, ret if, entrusted with a governmental charge, he knows not how to act, or if, when sent to any quarter on a mission, he can not give his replies unassisted, notwithstanding the extent of his learning, of what practical use is it ?203

Such a question would have been sacrilege to a Confucianist of a later day, when the Classics had become sacrosanct and their knowledge a badge of caste.

Confucius has been interpreted by various schools of thought, in East and West, to accord with their systems. Especially has there been an effort, under rationalistic influence, to make him a mere ethical teacher, without any system of metaphysics. Enough has been said, I trust, to discredit this position. To be sure, Confucius believed in the force of teaching and example, but he also

198 Ibid., 5,24.

199 Ibid., 7.26 .

200 Ibid., 7,32.

201 Ibid., 9,22.

202 Ibid., 10,15 .

202a Ibid., $5.1 ; 15,41$.

203 Ibid., 13,5 . 
believed that the same ends might be achieved without them if the transcendent harmony of the universe were brought about by the emperor, treading in the tao. He has been thought likewise to have been a sceptic on the subject of the existence of "spirits," the kwei 鬼 and the shên 耐. Perhaps he was, but our materials do not warrant the assumption.

Fan $\mathrm{Ch} \mathrm{i}$ asked what constituted wisdom. The Master said, "To give one's self earnestly to the duties due to men. and, while respecting the $k w e i$ and $s h \hat{c} n$, to keep aloof from them." 204

The rule of Confucius in regard to these beings, as in regard to all others, is to treat with them no more and no less than li prescribes, and in the manner which it prescribes.

The Master said, "For a man to sacrifice to a kwei which does not belong to him [is not of his family] is flattery."'

For this philosophy, as for any anthropocentric cosmology, the great problem is, of course, that of evil. If all which exists is properly part of the great harmony, and if at one time that harmony was in existence, how could it ever have ceased? This problem, Confucius never deals with. His practical emphasis did not admit of it. We must, however, consider his doctrine of human nature, since that has been called into question by Dubs. ${ }^{206}$ Dubs makes the flat statement that Confucius did not teach that human nature was originally either good or evil. ${ }^{207}$ He is mistaken, as the following quotations from the Analects will show.

The Master said, "Man is born for uprightness. If a man lose his uprightness, and yet live, his escape from death is the effect of mere good fortune. ${ }^{208}$

The Master said, "By nature, men are nearly alike; by practise, they come to be wide apart." 209

Nothing could be more explicit than these two statements. And it will be seen that this is the only position which is really consistent with pure Sinism. For properly and naturally all things were good, and it was only by perversion that they became evil. And likewise, all things properly worked out for the good, and evil was surely punished and virtue surely rewarded. It was a noble faith-too

204 Ibid., 5,20.

205 Ibid., 2,24,1.

206 H. H. Dubs, Hsïntze, The Moulder of Ancient Confucianism.

207 Ibid., p. 78-79.

208 An. 6,17.

209 An. 17,2 . 
noble to maintain itself intact in the evil times upon which China had come.

Yet we have not answered the question as to the origin of evil in this once perfect universe. Nor does Confucius answer it, in the Analects at least. One passage indicates that he would trace it to a gradual deviation from the original path of rectitude.

The Master said, "Extravagance leads to insubordination, and parsimony to meanness. It is better to be mean ${ }^{210}$ than to be insubordinate. ${ }^{211}$

It must be remembered, of course, that our record of Confucius' teachings is partial at best. But it is not probable that Confucius ever did meet this problem directly, for his interest was in practical statesmanship and social engineering, and he refused, like Gautama, to spin logical spider-webs. Such an emphasis was thoroughly compatible with his belief in the efficacy of certain techniques which we should call magical. To the man who uses magical technique, it is as much a valid and common-sense means of achievement as our magical category, "Science!", is to us.

The error of thinking Confucius a sceptic regarding the existence of superusual beings, which had its origin in this practical emphasis, has been touched on. His pragmatic attitude has been still further misinterpreted by Wieger to be "opportunism," action with a view to getting results without much reference to principle or means. ${ }^{212}$ It is not without whimsicality that Wieger, himself a Jesuit scholar, should libel Confucius with the very accusation of "Jesuitical" tactics which has followed his own order. IThat are the facts?

The Master said, "The superior man, in the world, does not set his mind either for anything or against anything; what is right he will follow." 213

"What is right he will follow." The character used here is $i$, but tao or $l i$ might be substituted equally well. If there exists in the world a more exacting code of principles than this one, I do not know it. Confucius means simply that a man is not to follow his own whims and personal opinions as over against the cosmically grounded principles of right action-a fundamental principle of Fr. Wieger's own Church. The learned Jesuit makes the mistake of believing 210 I.e., at all costs, order must be preserved.

211 An. 7,35.

212 Wieger, Histoire des Croyances, p. 133.

213 An. 4,10. 
that lack of Christianity means, ipso facto, lack of any body of settled principle.

Unsparing of himself, Confucius demanded that others, and especially those of his own class, the scholars in government service, should be equally selfless in working for the prevalence of the tao. Again and again he tells us that the man of complete virtue will give up his life if need be rather than violate it. No matter how ancient an agreement may be, it must be kept. One who calls himself a scholar, and yet who devotes himself to truth so little that he can be ashamed of bad food and bad clothes, is not worth talking to. He is especially scornful of the mercenary scholar.

The Master said, "With coarse rice to eat, with water to drink, and my bended arm for a pillow;-I have still joy in the midst of these things. Riches and honors, acquired by unrighteousness, are to me as a floating cloud."214

Is there any asceticism in Confucius' teaching? He does, to be sure, declare that it is not the part of the superior man to take undue enjoyment in fine food and ornamentation of his dwelling. He stigmatizes some music as "licientious," and he left the employ of the Marquis of $\mathrm{Lu}$, at the height of his own career, because the Marquis was devoting his time to dancing girls. Yet the objection in the latter case was chiefly, at least, that the Marquis was neglecting his governmental duties; in other cases, too, devotion to pleasure was disapproved because it made devotion to duties impossible. In each situation, $l i$ was the guide, and $l i$ was the code of good manners made sacred. Obviously, few ascetic practices could have been tolerated within it; even a slight deviation in dress was sacrilege. Mutilation of the body (although practised by the government as punishment) was a serious breach of filial piety if performed by the individual, since it destroyed part of what was given by one's parents. A good Chinese had too many duties, within the order of Sinism, to have time for much asceticism.

Confucius was by no means a foe to happiness. The bringing of universal happiness was, in fact, his great ideal, and he approves the enjoyment of life, in conformity with $l i$, wherever he finds it. On one occasion he asked several of his disciples to name their wishes. Three named more or less grandiose ambitions, to govern states well, and the like. Confucius turned to the fourth, who said: 
In this, the last month of spring, with the dress of the season all complete, along with five or six young men who have assumed the cap, and six or seven boys, I would wash in the $I$, enjoy the breeze among the rain-altars, and return home singing." The Master heaved a sigh and said, "I give my approval to Teen.'"215

Incidentally, this approval of participation in an ancient and homely rite by one of his disciples does not show Confucius as the rationalistic sceptic he has sometimes been made out.

Confucius' devotion to duty was intensified by a sense of mission such as most great men have had. He feels very definitely that he has been appointed by Heaven to further the tao, and that so long as this mission is yet to be fulfilled he can not be harmed..16 This was in part responsible for the very great personal courage which he displayed on several occasions. The corollary of this position, at which Confucius merely hints in moments of despair, is that Heaven is also responsible for his lack of success. Here again the problem of evil raises its head. Like his successors, Confucius seems to have been given to a degree of fatalism. ${ }^{217}$ Neither of these problems was recognized squarely until the time of IVang Ch'ung (the first century A. D.).

Sinism had as one of its integral parts, it will be remembered, the arrangement of society, as well as of authority, in a system of graded ramifications from the center, which might be compared to an arterial system. All were bound to the center, i.e., the emperor, but by a graded series, which extended from individuals to the head of the family, thence to the petty feudal lord, to the greater lord, and so on up to the imperial throne. It has been said that the theory of the empire was a magnification of the theory of the village. The village was a family, or a group of families; the empire was also conceived on the pattern of a great family. The centrality of the family concept in Confucius teaching was therefore thoroughly consistent. One of the very corner-stones of Sinism was the "five relations," that of father and son, of elder brother and younger brother, of husband and wife, of elders and juniors, and of ruler and minister. It will be seen that three of these are specifically within the family. These five relationships are mentioned in the Classics, from the earliest to the latest, as being of paramount im$215 \mathrm{An} .11,25,7$.

216 An. 7,22 ; 9,5; 14,37-38.

217 An. 12,5,3. 
portance. The family was, in fact, the most important Chinese institution, as it remains today. Religion and philosophy, which always rationalize the status quo, were inevitably built around this center. When Mo Tse treated family loyalties as of relatively little importance he was rightly accused of heresy from the ancient point of view. Confucius, in this as in most other matters, followed the ancient way.

The Duke of Shê informed Confucius, saying, "Among us here there are those who may be styled upright in their conduct. If their father have stolen a sheep, they will bear witness to the fact."

Confucius said, "Among us, in our part of the country, those who are upright are different from this. The father conceals the misconduct of the son, and the son conceals the misconduct of the father. Uprightness is to be found in this." 218

This does not mean, however, what has sometimes been attributed to Confucius, an attitude of indifference toward all but one's kin. He was a persistent preacher of altruism, which he also practised, and he advocated practical charity. It was only to the evil-doer who was not of one's kin that he denied the claim of help. Although, when asked to define benevolence, he replied, "It is to love men," he also said, "Recompense injury with justice, and kindness with kindness."

One of the chief reasons for which Confucius is important for sinology is the fact that he edited the Shi and the Shu. A vital problem, which will probably never be solved, concerns the extent to which he altered the materials which came to his hand. The matter has been referred to before, and little can be added here. The general opinion is that, while he eliminated much of what he found, he altered the remainder but little if at all. Confucius, in so far as we can see him, is a traditionalist, not an innovator. The true traditionalist may easily select those materials which harmonize with each other and with his own views, but his reverence for the past will probably interdict any great amount of tampering with those records which he believes correct and therefore sacred. We know that in at least one instance, that of the songs of Ch'ing in the $S h i$, Confucius included materials of which he violently disapproved. ${ }^{219}$

218 An. 13,18.

219 Analects, 15,10,6. C f . Legge's note, in Chincse Classics, v.I, p. 162. 
It is Confucius who gives us the first, the most complete, and the most faithful picture of the orthodox Sinism which had flourished up to his time. After him, and starting in his own day, we enter the period of criticism and of philosophical embellishment of the old sistem. As we have seen, there is little of this in Confucius, and the lack makes him invaluable. Had he been more original, he would be less important for this study.

In treating next of Mencius, we take up the most important successor of the Master, often called the Second Sage, and credited with having given its wide vogue to the teaching of Confucius. We skip a hundred years, to which we must return later to deal with those trends of thought which differed more from the way of the ancients.

Mencius is the latinization of Meng Tse. The philosopher: who lived from 372 to 289 B. C., ${ }^{220}$ was born in Confucius' native state of $\mathrm{L}$. He received his training, it is recorded, from the sole grandson of Confucius, who is generally agreed to be the author of the Chung Iung or Doctrine of the Mean, which is the third of the Four Books. The book of Mencius, entitled simply by his name, is the fourth and last of these documents, which might together be called the "New Testament" of the Confucian school. Mencius" book is said to have been written by himself, but there is reason to beliere that it was probably composed after his death by a disciple. This was the more usual procedure.

Mencius, like Confucius, travelled widely, but the object of his travels was very different. Confucius sought, above all, an opportunity to put his principles into practice: Mencius, although he occasionally held office, relinquished it easily, and sometimes for reasons which seem to be mere petulance. On one occasion he complains that a king who had employed him did not really want him, else he would have kept a representative perpetually beside the philosopher to compliment him and assure him of the great esteem in which the king held his services, and of how sorry the ling would be to lose him ! 221

The fact is that Mencius was a philosopher and a teacher, while Confucius before him was primarily a man desperately concerned to save the empire. Mencius really cares far more that his own brilliance shall be recognized, and that his dignity shall be un-

220 Wieger, Histoire des Croyances, p. 226.

221 Mcncius 2(2), 11. 
impaired, than for the prevalence of that hazy thing called the tao, which is so far away and which Heaven itself does not yet wish to prevail. The rôle of harsh and unbending critic, which he filled to perfection, suited him far better than did that of practical reformer. In originality, and in intellectual penetration, he far outshone Confucius; in personal greatness he is not to be compared with him. For some incomprehensible reason, the opposite view seems to have gained currency in the West.

Mencius is conspicuously lacking in that uniform courtesy and kindness which was perhaps the outstanding characteristic of the great Master. ${ }^{222}$ He considered himself so eminent that it was the place of kings to approach him for advice, rather than for him to go to them (one can hear, and enjoy, the stinging rebuke which Confucius must have uttered from the tomb for this arrogant breach of $l i$. $)^{223}$ Time after time he dodges the issue when questioned, saving his reputation for omniscience by a bit of cleverness. ${ }^{24}$ On one occasion, when asked by the ruler of Ts'e if the state of Yen might properly be attacked, he answered "It may." But when, after the attack had been made, he was accused of having countenanced an unjust aggression, he denied the charge. He had only been asked, he declared, if the State might be attacked, nothing had been said of who might properly conquer it. Oh, by no means. he had not advised the attack!225 Confucius despised such slyness.

On the other hand, the good qualities of Mencius were not a few. His loyalty to the memory of Confucius is implicit. He does not hesitate to decline large sums of money offered him, though he accepts gifts when in need. And his very arrogance compels our admiration when he carries it, as he often did, to the point of telling a king to his face that he ought to be put to death if he does not govern his kingdom well. ${ }^{226}$ And it is Mencius who has given us our most inspiring statement of the ancient Chinese ideal of character.

To dwell in the wide house of the world, to fill his correct place in the world, and to walk in the great tao of the world; when he obtains his desire for office, to practise his principles for the good of the people; and when that desire is disappointed, to practise them alone; to be above

$222 \mathrm{Mcn} .2(2), 11$, etc.

223 Men. $2(2), 2,7$.

$224 \mathrm{Men} .6(2), 1$; etc.

$225 \mathrm{Men}$. 2(2),8.

226 Mcn. 1(2),8,2; 5(2),9,1. 
the power of riches and honors to make dissipated, of poverty and mean condition to make swerve from principle, and of power and force to make bend:- such is the man who may be called truly great and courageous. ${ }^{227}$

After Confucius, the integrity of the old Sinism, as a metaphysical system, began gradually to disintegrate, but the enfeeblement in Mencius is very slight. Mencius still insists that to follow the tao absolutely is the way to bring about felicity, and declares that a king who fails to do so is responsible for the death of his subjects as surely as if he put them to the sword. ${ }^{228}$ The power of virtue is so great that the untrained peasants of a state which practises righteousness, though they be armed but with sticks, will utterly rout the mail-clad soldiers of a state which has forsaken the tao. Likewise, there will be no famine if only agriculture, fishing, etc., be carried on in the proper and prescribed manner. On the other hand, if the people are not given the benefit of the Confucian teaching, but are led astray by the perverse doctrines of Yang Chu and Mo Tse, they will forsake the tao so far that the harmony of the world-order will be shattered, and beasts will be led on to eat men-more, men will take to eating each other. ${ }^{229}$ All of this is in strict conformity with Confucius.

But Mencius says other things which Confucius would never have said. These aberrations are due, not so much to a genuine difference in philosophy, as to an inability clearly to hold in mind, at the same time, all of the various elements of the Sinistic system. Mencius was incisive and analytical, but neither he nor any of the other later philosophers of the period had the mellowness, the breadth of wisdom, and the firm intellectual grasp of the old philosophy which Confucius had. This may have been due in part to the fact that Confucius taught himself, and did not receive a "predigested" system from a master.

When asked by a king what was necessary in order to attain the imperial sway, Mencius replied, "The love and protection of the people; with this there is no other power which can prevent the ruler from attaining it." ${ }^{30}$ Again, he approves the appointment. as minister, of a scholar who is neither vigorous, wise, nor well informed, but whose sole qualification is that he loves what is good.

$227 \mathrm{Mcn}$. 3(2),2,3.

228 Mcn. 1 (1),2,2; 1 (1), 4,3.

$229 \mathrm{Men}$. 3(2),9,9.

230 Men. $1(1), 7,3$. 
Questioned on the point, Mencius declares that "The love of what is good is more than a sufficient qualification for the government of the empire."'231 Now, this is scandal from the ancient point of view. To be sure, motivation must be correct, but in addition a man had to know $l i$ (Confucius stresses learning more than piety) and he had actually to follow the tao, properly performing the necessary rites and duties. Were Mencius here, his ubiquitous cleverness would provide the answer that of course, if a man really loved what was good, this action would follow as a matter of course. But we must over-rule the objection. Unwittingly, he was helping in the gradual corruption of the old philosophy. His stand on tradition represents another divergence, for he tells us that

"It would be better to be without the Book of History [the Shu] than to believe all of it."

Confucius was not a book-worshipper, but he would have asked which were better, to have a book with a few errors, or to lack the tao entirely?

Concerning the nature of man Mencius is, however, in essential agreement with Confucius, though Dubs has denied this. As is well known, Mencius teaches that men are naturally good, and this is, as has been shown, in conformity with Sinism. He shows great ingenuity in defending this position against attacks. It is, apparently, their understanding of the tao which distinguishes men from the beasts.

"Men possess the tao; but if they are well fed, warmly clad, and comfortably lodged, without being taught at the same time, they become almost like beasts."'232

"That whereby man differs from the lower animals is but small. The mass of people cast it away, while superior men preserve it." 233

Mencius further says that the man who knows his own nature thoroughly knows Heaven. This would seem to be based on the organic unity and harmony which pervade the cosmos. Another reminder of the natural philosophy is the fact that men, like other objects, differ among themselves not in substance but in action. Any man may be like Yao or Shun, if his conduct be so. ${ }^{234}$

But still we ask why, starting equal, men become so widely $231 \mathrm{Men} .6(2), 13$.

$232 \mathrm{Men} .3(1), 4,8$.

$233 \mathrm{Men} .4(2), 19,1$.

${ }_{234}$ Men. $4(2), 28 ; 4(2), 32$. 
different? The only clear answer which Mencius gives refers us to environment. He uses the figure of a field of barley, sown with the same seed, but giving an unequal yield in different sections: this is due, he says, to inequalities of soil, rain, and dew, and to unequal cultivation of the various portions. He rejects all hereditary differences. Another time, when hard pressed. he answers:

"The senses of hearing and seeing do not think, and are obscured by objects. When one thing comes into contact with another, as a matter of course it leads it away. To the mind belongs the office of thinking. By thinking, one attains the truth; by neglecting to think he fails to do so." ${ }^{235}$

But he has not yet told us why it is that one man thinks, and another fails to, although he pretended to answer that very question. This throws him back on the first portion of his statement, which is much like contemporary deterministic behaviorism. In fact, Mencius is much inclined to fatalism. He declares that Heaven does not yet wish the right to triumph, and proclaims a doctrine familiar to the West, that Heaven sends calamities in order to strengthen men. Although cheerfully ascribing some of his own failures to destiny, he adds that the man who properly understands the decrees of Heaven will not stand beneath a precipitous wall.

Mencius could afford to be a fatalist. The plight of the Empire was not a matter of burning personal distress to him. His most biting criticisms only exalted his fame and his self-esteem, and in any case his needs were well taken care of. He was received with the greatest respect. even kings quailed before him-he was having a very good time. "It is fate"-well, why not?

Mencius' chief claim to intellectual distinction lies, probably, in his social psychology. He declares that all possess the capacity of natural sympathy.

"If men suddenly see a child about to fall into a well, they will all without exception experience a feeling of alarm and distress. They will feel so not as a ground on which they may gain the favor of the child's parents, nor as a ground on which they may seek the praise of their neighbors and friends, nor from a dislike to the reputation of having been unmoved by such a thing." 236

From this point he builds, in outline, an entire system of ethics, which, being so firmly grounded, is not without force today. His criticism of the ethic of "enlightened self-interest" is penetrating. ${ }_{235} \mathrm{Men} .6(1), 15 . \quad 236 \mathrm{Men} .2(1), 6,3$. 
It is impossible, on this basis, to build a genuinely cooperative society, he asserts, because at the end one still has no more than a group of self-seeking individuals, whose reactions in crises may not be depended upon to be social. ${ }^{237}$

In next considering Hsün Tse, we come to a philosopher who is, in the history of Chinese thought, a figure of paradoxes. Dubs calls him "the moulder of ancient Confucianism," and he is one of the most important Confucianists in history; as a matter of fact, he is the destroyer of the principles of Confucius, for he utterly and explicitly denied and rejected the heart and soul of Sinism. Lao Tse and his teachings are considered the arch-opponents of Confucius, and Hsün Tse is considered a disciple of the latter. Yet, as compared with Hsün Tse, Confucius and Lao Tse stand solidly together on the basis of Sinism, which Hsün Tse discarded.

It is evident that the technique by which Hsün Tse nullified the teachings of Confucius must have been subtle. It was. And yet it is the simplest and most usual technique imaginable. Hsün Tse simply "modernized" and "interpreted" Confucius. The procedure is that which has been used numberless times, and is still used, to substitute some more favored philosophy for the teachings of Gautama, Zoroaster, Mohammed, Jesus, or another, while at the same time preserving for the substituted system the prestige of the famous teacher. In most cases, the persons who make the change are quite sincere, and innocent of any intent to deceive. This was true, I believe, of Hsün Tse.

The life of Hsün Tse is little known. Dubs dates him as having lived approximately from 320 to $235 \mathrm{~B}$. C. Hsün Tse strikes one as a man more interested in his task than in himself. He lived toward the end of the period of the "Warring Kingdoms." The time was one of constant bloodshed and ruin. The fifty-five states, which had been, were now consolidated to ten, but the struggle went on more fiercely than ever between these. A student of Hsün Tse, Han Fei Tse, was counselor to the T'sin emperor who finally did consolidate China, but this was after the time of Hsün. His day was one of slaughter, licence, and sophistry. From this came his very low estimate of human nature, cardinal in his philosophy. He saw that while the idealism of Confucius might have worked in the ancient "Age of Peace," something sterner was needed for his own "Age of Trouble." He did not attain fame until middle $237 . M e n .6(2), 4$. 
age, and it is probable that he had already worked out his own ideas, at least in outline, before he came in direct contact with the Confucian tradition.

What Hsün Tse does is to retain the outward forms of Confucian ethics and politics, while discarding the cosmic sanctions and metaphysical guarantees which were central for Confucius. For Hsün Tse, Heaven is merely the active principle, invisible and impalpable, which pervades all beings in the whole world. It is wrong to say that good and bad fortune come from Heaven. Drouths, floods, etc., are merely the natural activities of the cosmos, which may injure men but do not do so intentionally; it is for man to use his intelligence and industry to provide against these things, and so to make himself independent of Heaven and earth. ${ }^{23 s}$ Ancient tradition should be followed in government because it is, after all, that which has proved useful in experience, but it is to be used experimentally, and modified and adapted to suit new conditions. Confucius and his disciples were wrong in considering it an absolute standard, to be applied as found in the Classics. ${ }^{239}$ The right of revolution is affirmed, but Hsün Tse declares that Heaven has nothing to do with the tenure of kings. The "Decree of Heaven" is "what one meets at the moment." "The supernatural sanction is entirely gone." ${ }^{2 \pm 0}$ Hsün Tse agrees with Confucius and Mencius in deploring war, which disrupts society and causes misery, and like them he declares that righteousness is worth more than a standing army. But they believed that this was true because Heaven prospered the man who followed the tao, and the whole universe was with him. Hsün Tse's argument is that all the people would love a good ruler so much that it would be impossible to get an army to oppose him. ${ }^{241}$ Again, he says:

If a man's deportment is respectful, his heart loyal and faithful, his methods according to the rules of proper conduct and justice, and his ruling passions love and benevolence, were he to rule over the empire, although he were harassed by the four barbarian tribes, the people would not fail to honor him. ${ }^{242}$

But Confucius would have declared that such a ruler could not possibly have been harassed by anything or anybody, else the very structure of the universe must have been altered.

238 Wieger, Histoire des Croyances, p. $277 . \quad 239$ Ibid., p. 280.

240 Dubs, op. cit., p. 260. Cf. also p. 54.241 Ibid., pp. 268-69.

242 Ibid. p. 258. 
How could Hsün Tse pass such teachings as true Confucianism? In the first place, he attributed his own contempt of human nature to Confucius. He declared that Confucius realized that the men of his time did not wish to see the real truth. For this reason Confucius gave them the ancient axioms, to be accepted as a matter of faith. Common men believe, and wait foolishly for Heaven to help them. But the sages, Hsün Tse assures us, use their own wits and ability to solve their problems, and worry little or not at all about Heaven. The sages know that the speaking of the ancestors through the tortoise and the milfoil, the bringing of rain by prayers and offerings, etc., are only ways of explaining obscure natural phenomena to the unintelligent people. ${ }^{243}$

This is the old doctrine of the "symbolic scriptures" and the "esoteric tradition." That Hsün Tse should have used it is natural, but that he should have succeeded in imposing the unconscious fraud, not only upon a large portion of subsequent Chinese Confucianism, but on a large portion of modern Western scholarship. is astounding. Yet it is Hsün Tse's Confucius that many of us are given today - a rationalistic sceptic, looking down on, but tolerating for pragmatic reasons, the silly superstitions of people and princes. Dubs says of Hsün Tse, "His logical mind grasped the Confucian philosophy in systematic form, and he set to work to express and defend the Confucian teaching in its wholeness as none before him had done." On this point, either Dr. Dubs has misunderstood Confucius, or I have. Let those who are competent judge.

First of all, it is beyond question that the Classics are saturated with the metaphysical relation existing between Heaven, men, and all things. This is that universal harmony which composes the tao. But did Confucius, as Hsün Tse declared, have his tongue in his cheek when he pretended to take this seriously? To answer this question it is necessary to live with the Analects for a time, and to come to know Confucius well. No mere citation of passages can settle the point; we must, however, be content with that here. No one who has read the Analects will doubt that Confucius mentions the sacrifices very often. But did he believe in their efficacy?

Some one asked the meaning of the great sacrifice. The

Master said, "I do not know. He who knew its meaning would find it as easy to govern the empire as to look on this ;"-pointing to his palm. ${ }^{244}$

243 Wieger, Histoire des Croyances, pp. 277-79. $\quad 244$ An. 3,11. 
It has already been shown that Confucius felt a very definite personal relation with Heaven.

He [Confucius] said, "After the death of king Wan, was not the cause of truth lodged here in $m e$ ? If Heaven had wished to let this cause of truth ${ }^{245}$ perish, then $I$, a future mortal, should not have got such a relation to that cause. While Heaven does not let the cause of truth perish, what can the people of K'wang do to me?" $2+6$

I do not murmur against Heaven. I do not grumble against men. My studies lie low, my penetration rises high. But there is Heaven; - that knows me! $!^{247}$

Hsïn tells us that the sages were far above the belief in divination, omens, etc., which the foolish people clung to. Why, then, does Confucius declare that his decay is extreme merely because for a long time he has not seen the Duke of Chow (whom he considered his preceptor) in his dreams? Why is the low point of the Analects the passage in which Confucius declares that all is over with him, because no phoenix has been seen, and the river has given forth no map? $?^{2+8}$ All of these are traditional omens of political good fortune.

According to Hsïn Tse, law ( $f a$ 法), propriety ( $l i$ 禮), and righteousness ( $i$ 義), are not natural, but are artificial restraints devised by the sages to make a sort of straight-jacket in which to confine evil-natured humanity. Thus, the tao was empirically established, and is from time to time revised and amplified. ${ }^{249}$ Is this experimental, piecemeal, non-cosmic ethics the true spirit of Confucius' teaching? Emphatically, no!

The Master said, "Ts'ze, you think, I suppose, that I am one who learns many things and keeps them in memory?", Ts'ze-kung replied, "Yes,-but perhaps it is not so?" "No," was the answer: "I seek an all-pervading unity." "2." The Master said, "Sin, my tao is one pervading principle."251

Confucius declares, "Heaven produced the virtue that is in me," ${ }^{252}$ and asserts that if it be so ordered that his tao is to advance.

245 I am aware of the difficulty of this translation, but I believe this rendering is substantially accurate.

246 An. 9,5 .

247 An. 14,37,2.

248 An. 7,$5 ; 9,8$.

249 Wieger, Histoire des Croyances, p. 276.

250 An. 15,2 .

251 An. 4,15 .

252 An. 7,22. 
no mere mortal can prevent it. ${ }^{253}$ Confucius was one of the most firm believers in metaphysics who ever lived, as Hsïn Tse was one of the most thorough-going naturalists of ancient times.

Among certain of the American Indians there are medicine-men, who heal disease by magical ceremonies in which the sweat-bath figures as a part. Certain scientific medical practitioners also use the sweat-bath in healing. May we say, because their technique coincides in this case, that their theory of healing is the same? If their technique coincided in a hundred instances, we would still not infer that their philosophies were alike, nor that they would approach new problems in an identical manner. The analogy applies to Confucius and Hsün Tse. On empirical grounds Hsün Tse took over many of the moral axioms, etc., of Confucius. Hsün Tse thought they had worked, because the history, written by men pervaded with Sinism, showed that they always had worked. But Hsün Tse's theory was far different; on his principles, if these axioms failed to work in the future, they must logically have been discarded. According to Confucius, on the other hand, the only remedy for the failure of Sinism was "more Sinism."

Since he refused to accept truth as an absolute datum, cosmically established, Hsün Tse needed a theory of knowledge. It was very much the theory we have today, simply that truth is that which we arrive at when we do the best thinking of which we are capable. He carefully laid down the conditions for thought, with especial reference to lack of bias and disturbance of any sort. For this reason he has sometimes been said to have borrowed the "meditation" of Laoism, but this seems improbable. His dependence on that school of thought has probably been exaggerated, although it probably did influence him. Hsün Tse's distrust of human beings in general made him unwilling to leave thinking to the tender mercies even of the scholars, and led him to set up his theory of authoritarianism.

The doctrine that human nature is evil, and that man's goodness "is only acquired training," is Hsün Tse's most famous teaching, and caused him to be declared unorthodox. He "showed that according to Mencius' statement that virtue was just the development of innate impulses, there would be no use for the Sage-Kings or for any standards of conduct at all, such as those embodied in the concepts of $l i$ and $i$ (proper conduct and justice). Here he 253 An. 14,38,2. 
made a criticism," Dubs comments, "that must have cut very deep." ${ }^{254}$ On the contrary, the objection is easily met. Dubs, like Hsün Tse, fails to recognize the central dogma of Sinism, that goodness (i.e., harmonious cooperation) is the natural, normal, proper state of all things. In the "Golden Age" men were born good, kings were sages, animals did not eat men, men were kind to each other and to animals, men followed $l i$ without the necessity of punishment and kings were good without admonishment from their ministers, all as a part of the naturally ordained scheme of things. It is evil (i.e., disharmony) which is unnatural, abnormal, and transient. As Confucius said, "Man is born for uprightness. If a man lose his uprightness and yet live, his escape from death is the effect of mere good fortune." ${ }^{255}$ It is the existence and persistence of evil, not of good, which should provoke astonishment.

As we have seen Hsïn Tse so far, he is the freest thinker and the most modern spirit we have encountered. Given his empirical and experimental method of attaining and amplifying ethics and politics, we might expect that China would have made unprecedented strides of social and political amelioration. But here we encounter the final paradox of this remarkable man. As he was, in his opinions, the least traditionally-minded of his fellows, he was, in his theory of education, the most rigid authoritarian. He distrusted men, and was unwilling to allow them to think ad libitum. The thought of what may have been lost, by that lack of faith, is staggering. There is no other knowledge, he asserted, than the knowledge of the ancients. To acquire that knowledge it is necessary, not to think, but to listen to one's teacher. The student's studies are finished when he has so thoroughly learned the teachings of his master, and especially the $L i K i$, that he is able to become the echo of his teacher for a new generation. ${ }^{256}$ This rigid authoritarianism was fixed upon the Confucian school from his time.

But his rationalistic basis of ethics, and his related doctrine of the viciousness of human nature, were too heterodox and too heroic for most of the members of the Confucian school. And it is for this reason that Sinism survived, past the time of Hsün Tse, as something more than an external shell of precepts without a living heart.

254 Dubs, op. cit., p. 81.

255 An. 6,17.

256 Wieger, Histoire des Croyances, 282. 